\title{
Alunite formation within silica stalactites from the Sydney Region, South-eastern Australia
}

\author{
Robert A.L. Wray ${ }^{1}$
}

\begin{abstract}
:
Robert A.L. Wray 2011. Alunite formation within silica stalactites from the Sydney Region, South-eastern Australia. International Journal of Speleology, 40 (2), 109-116 Tampa, FL (USA). ISSN 0392-6672. DOI 10.5038/1827-806X.40.2.3

This paper presents X-ray diffraction and SEM evidence for the formation of alunite, and possibly small quantities of natroalunite, within opal-A stalactites formed on quartz sandstone near Sydney in south-eastern, Australia. Alunite has been reported as a speleogenetic mineral from sediments within a number of caves around the world, but this is believed to be the first report of speleothemic alunite in opaline silica speleothems. Individual alunite crystals have not been visually identified, but SEM X-ray element mapping suggests the alunite has formed amongst kaolinite clay. Sedimentary alunite and natroalunite formation is usually associated with the reaction of sulphuric acid on illite, smectite and kaolinite clay materials. In this location groundwater sulphate levels are not high, but evaporative concentration of stalactite drip-water containing small amounts of sulphuric acid generated by oxidization of pyrite might lower the pH to a level sufficiently acidic for conversion of kaolinite or illite to alunite. The ferrolysis of hydrous $\mathrm{Fe}^{2+}$-oxides, or the biochemical activities of bacteria or other micro-organisms, also provide conceivable pathways for the generation of $\mathrm{pH}$ sufficiently low to contribute to alunite formation. The occurrence of alunite in these silica stalactites, whilst unusual, is consistent with the normal silica stalactite-forming process in this region, and in accord with observations of the authigenic formation of alunite and groundwater opal in weathering profiles elsewhere.
\end{abstract}

Keywords: alunite, natroalunite, opal-A, apeleothem, atalactite

Received 15 December 2010; Revised 28 January 2011; Accepted 20 February 2011

\section{INTRODUCTION}

The formation of alunite within stalactites at normal atmospheric temperatures $\left(10\right.$ to $\left.30^{\circ} \mathrm{C}\right)$ has to our knowledge not been reported previously. This paper presents evidence for the authigenic formation of alunite, and possibly lesser quantities of natroalunite, within small opal-A stalactites from the Sydney region in south-eastern Australia. Based on microscopic and preliminary geochemical evidence a possible formative mechanism can be suggested.

Alunite, hydrous potassium aluminium sulphate $\left(\mathrm{KAl}_{3}\left(\mathrm{SO}_{4}\right)_{2}(\mathrm{OH})_{6}\right)$, is a member of a solid solution series of sulphuric acid indicator minerals that include natroalunite $\left(\mathrm{NaAl}_{3}\left(\mathrm{SO}_{4}\right)_{2}(\mathrm{OH})_{6}\right)$ and jarosite $\left(\mathrm{KFe}_{3}\left(\mathrm{SO}_{4}\right)_{2}(\mathrm{OH})_{6}\right)$, which respectively substitute $\mathrm{Na}^{+}$ for $\mathrm{K}^{+}$and $\mathrm{Fe}^{3+}$ for $\mathrm{Al}^{3+}$ (Dill, 2001). Chitale \& Güven (1987) classify the term 'alunite' as members in which $\mathrm{K}>\mathrm{Na}$, and 'natroalunite' those in which $\mathrm{Na}>\mathrm{K}$.

Alunite typically forms by the reaction of sulphuric acid, produced by the oxidation of sulphides, with potassium- and aluminium-rich rocks or clays (Khalaf, 1990; Hill \& Forti, 1997; Dill, 2001; Polyak \& Provencio, 2001; Deyella et al., 2005; Mutlua et al., 2005; Ece \& Schroeder, 2007; Ece et al., 2008). It is therefore a relatively common geothermal or hydrothermal-alteration product (Raymahashay,

${ }^{1}$ Fellow, School of Earth and Environmental Sciences,

University of Wollongong, Australia
1968; Stoffregen et al., 1994; Deyella et al., 2005; Mutlua et al., 2005; Ece \& Schroeder, 2007; Ece et al., 2008). But alunite also forms in low-temperature supergene (Bird et al., 1989, 1990; Stoffregen \& Alpers, 1992) and sedimentary/diagenetic or deepweathering environments (Goldbery, 1980; Chitale \& Güven, 1987; Khalaf, 1990; Alpers et al., 1992; Long et al., 1992; Thiry et al., 2006; Blanco et al., 2008).

In the context of caves and cave deposits, primary speleogenetic (formed within caves) alunite-group minerals have been found in the wall and floor sediments of a number of caves worldwide, where they are regarded as a clear indicator of the alteration of smectite, illite and kaolinite by sulphuric acid (Hill \& Forti, 1997; Polyak \& Provencio, 2001). Probably the best examples are found within the caves of the Guadalupe Mountains in New Mexico, including Carlsbad Cavern and Lechuguilla Cave (Polyak \& Güven, 1996; Polyak et al., 1998; Polyak \& Provencio, 2001). The timing of origin of some of these caves has been determined by ${ }^{40} \mathrm{Ar} /{ }^{39} \mathrm{Ar}$ dating of this alunite to over 11 Ma (Polyak et al., 1998; Polyak \& Provencio, 2000).

However Hill \& Forti (1997), in their benchmark review of cave minerals, note that alunite is very rarely found as an authigenic speleothemic mineral (formed within speleothems). They only report one instance of alunite-bearing stalactites, from a Sicillian lava tube where the mineral appears to have formed at elevated temperature. Further, there appears to be 
only one previous known instance of low-temperature speleothem alunite (Martini, 1980; Martini et al., 1997); in the Eastern Transvaal, where alunite is found as powdery pale-green nodules in gypsumrich 'speleothems' on cave sediments, but not in silica stalactites. This depositional environment and possible genesis pathways are in some ways similar to the present location. To our knowledge natroalunite has not been reported in any cave or speleothem context (Hill \& Forti, 1997).

Most speleothems are composed of calcium carbonate. However small opal-A stalactites are found at a number of locations around the world (Urbani, 1976; Briceño \& Schubert, 1990; Wray, 1997a; Carreño \& Urbani, 2004; Wiegand et al., 2004; Young et al., 2009) and their occurrence and formation on quartz sandstones within the Sydney region has previously been discussed (Wray, 1997a,b, 1999). However the presence of alunite within some of these stalactites has not previously been described. This may also be the first report of low-temperature alunite in stalactitic speleothems.

\section{FIELD LOCATION}

Opal-A stalactites are widespread, but not particularly common, on some quartz sandstones of the Sydney region in south-eastern Australia. However alunite-bearing stalactites have to date only been found within a single sandstone overhang-cave near Bundanoon, approximately $200 \mathrm{~km}$ southwest of Sydney. The climate is humid temperate with an annual precipitation of just over $1000 \mathrm{~mm}$ distributed evenly throughout the year.

This medium-sized (approx. $20 \mathrm{~m} \times 5 \mathrm{~m} \times 2 \mathrm{~m}$ ) cave is at approximately $630 \mathrm{~m}$ elevation and has formed at the foot of a $15 \mathrm{~m}$ high cliff in the quartzose fluviodeltaic Mid-Triassic Hawkesbury Sandstone.

This sandstone is an essentially flat-lying, crossbedded, very fine to pebbly quartz arenite that averages more than $75 \%$ detrital and overgrowth quartz, $2 \%$ feldspars and mica, and $2 \%$ rock fragments (Standard, 1969). Kaolinite and minor illite matrix clays are generally up to $20 \%$ of the total rock composition (Bayliss et al., 1965; Pells, 1977). Siderite accounts for around $1 \%$ to $4 \%$ of the total, but quantities of calcite $(<0.1 \%)$ or other minerals are very low (Standard, 1969; Herbert \& Helby, 1980).

About 2 to $3 \mathrm{~m}$ below this cave is a disconformable boundary to underlying estuarine/marine sandstones, mudstones, black shales and coal of the Permian Illawarra Coal Measures. Sulphur-rich minerals including pyrite are common within these underlying rocks (Standard, 1969; Herbert \& Helby, 1980).

\section{SPELEOTHEM DESCRIPTIONS}

In the Sydney region dissolved silica precipitates from evaporating groundwater as a range of small speleothems including stalactites, or much rarer stalagmites and flowstones. These speleothems are clearly forming under atmospheric conditions (Wray, 1997a,b, 1999). The alunite-bearing stalactites discussed here are of identical appearance and microscopic structure to the region's other silica stalactites and appear to form in a similar manner (Wray, 1997a,b, 1999). They are typically $1 \mathrm{~mm}$ to 50 $\mathrm{mm}$ in length, $0.5 \mathrm{~mm}$ to about $5 \mathrm{~mm}$ in diameter, and display either a gently tapering conical form or an irregular branching coral-like configuration. Very tiny droplets of groundwater may sometimes be seen on some of these stalactites.

\section{ANALYTICAL METHODS}

Ten stalactites, samples of the Hawkesbury Sandstone to which they were attached, and groundwater from nearby springs were collected for laboratory analysis. Optical thin-sections of the stalactites were examined under ordinary and polarised light, and freshly broken samples were viewed with a scanning electron microscope (SEM) equipped with an X-ray energy-dispersion detector (EDS) for elemental analysis and mapping. X-ray powder diffraction (XRD) and X-ray fluorescence (XRF) were used for mineral and elemental identification. Other chemical analysis were performed by ICP-OES, CNS analyser and electron microprobe. The chemical composition of springwater was determined by ionchromatography.

\section{Stalactite X-ray diffraction}

The Hawkesbury Sandstone is a relatively mature quartz sandstone, and Dill (2001) notes that pure sandstones that are not highly weathered or hydrothermally altered rarely contain alunite-group minerals. Such is the case with the sandstone to which these alunite-bearing stalactites were attached, and no alunite minerals have been previously found within this sandstone. X-ray diffraction spectra of the whole rock at this site only showed peaks of quartz, kaolinite, a little illite, and possibly a trace of muscovite and siderite.

Evidence for alunite and possibly smaller amounts of natroalunite within these stalactites is provided by five independent $X$-ray diffraction spectra, including at least three duplicates (Fig. 1). No other Sydney region silica speleothem has displayed similar patterns.

Very clear diffraction peaks of quartz (chalcedony) were obtained from each analysed stalactite. These were therefore used as an internal diffraction standard between individual samples.

Each of the XRD spectra shows the broad diffuse opal-A hump (Jones \& Segnit, 1971; Finlayson \& Webb, 1985) and the sharp peaks of quartz (chalcedony) and kaolinite typical of other Sydney region silica stalactites (Wray, 1997b, 1999). But what is unusual are prominent peaks at $4.96 \AA$, $3.49 \AA$, $2.99 \AA, 2.29$ $\AA$ and $1.92 \AA$. Although some minor alunite peaks are not discernable above the opal-A background, and whilst there is not a perfect match with all peaks, the general pattern fits that of alunite, and no other explainable mineral seems to fit such a peak pattern.

Samples 5, 9 and 10 show additional, less clear, peaks at $4.90 \AA, 3.49 \AA, 2.97 \AA, 2.96 \AA, 2.22 \AA$ and $1.89 \AA$ which may suggest the presence of some natroalunite (Brindley \& Brown, 1980). However the diffraction patterns are not sufficiently clear for unambiguous identification of natroalunite. 


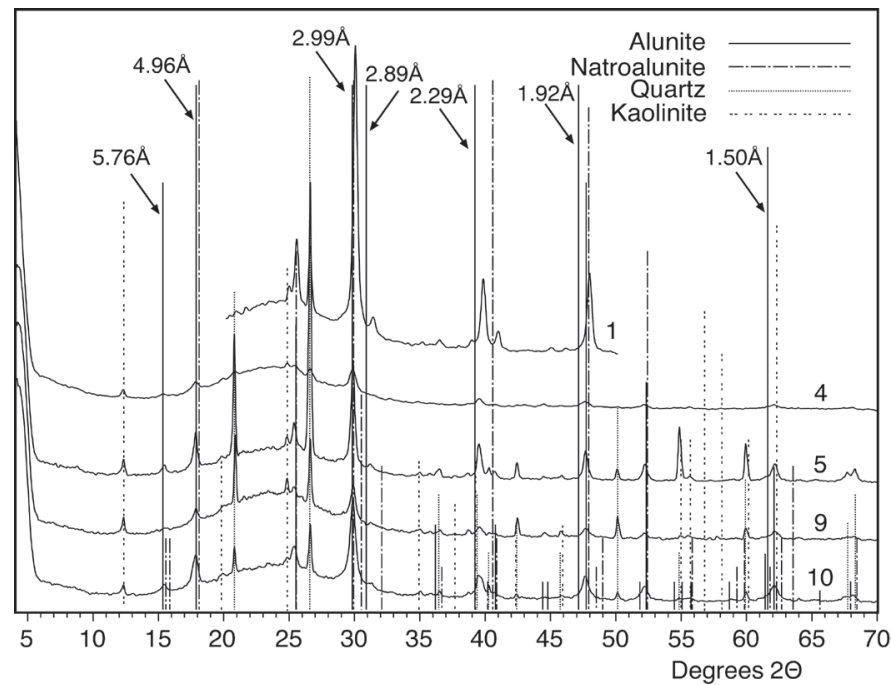

Fig. 1. X-ray diffraction spectra of five opal-A stalactites (BUND1, 4 , 5,9 and 10). The d-spacings of major alunite peaks are indicated. The individual spectra have been vertically offset for clarity. Note the broad amorphous opal-A hump between approximately $15^{\circ}$ and $35^{\circ}$ and the sharp peaks of alunite, quartz and kaolinite. Also note the variations in peak intensity between samples, and how BUND1 appears to possibly contain natroalunite. The spectrum for BUND1 was only measured between $20^{\circ}$ and $50^{\circ}$.

This XRD evidence appears to suggest the identification of alunite, and perhaps also natroalunite, but it is also possible that based on their solid solution series chemistry (Dill, 2001) and similar D-spacings a proportion of an intermediate alunite/ natroalunite end-member may also be present. Either way, such minerals have not been identified in silica speleothems before.

\section{Stalactite microscopic examination}

Optical thin-section and SEM examination showed these stalactites to be visually identical to those reported for other similar silica stalactites from this region (Wray, 1997b, 1999). Optically the microscopic structure is complex and composed of many distinct wavy $0.007 \mathrm{~mm}$ to $0.15 \mathrm{~mm}$ thick layers of dark grey to red-brown amorphous opal-A, alternating with layers of a mixture of opal-A and colourless, fibrous, lengthfast, crypto-crystalline chalcedony. These layers are arranged annularly around the central stalactite axis and parallel to the stalactite surface, but there is no central drip-water hole. Significant amounts of kaolinite along with red-brown and opaque amorphous iron oxides and hydroxides are common within the opal-A layers, as are numerous other opaques (moss, bacteria, dust, etc.) (Wray, 1997b, 1999).

SEM examination showed a very large number of irregularly packed, $0.5 \mu \mathrm{m}$ to $15 \mu \mathrm{m}$-sized grains of non-biogenic opal-A (Fig. 2). These silica 'flecks' appear to be precipitating from evaporating silica-rich water, and over time may slowly 'mature' by Ostwaldtype paragenesis to crypto-crystalline chalcedony (Wray, 1999). These observations are similar to those found for silica stalactites elsewhere in the world (Urbani, 1976; Briceño \& Schubert, 1990; Carreño \& Urbani, 2004; Wiegand et al., 2004).

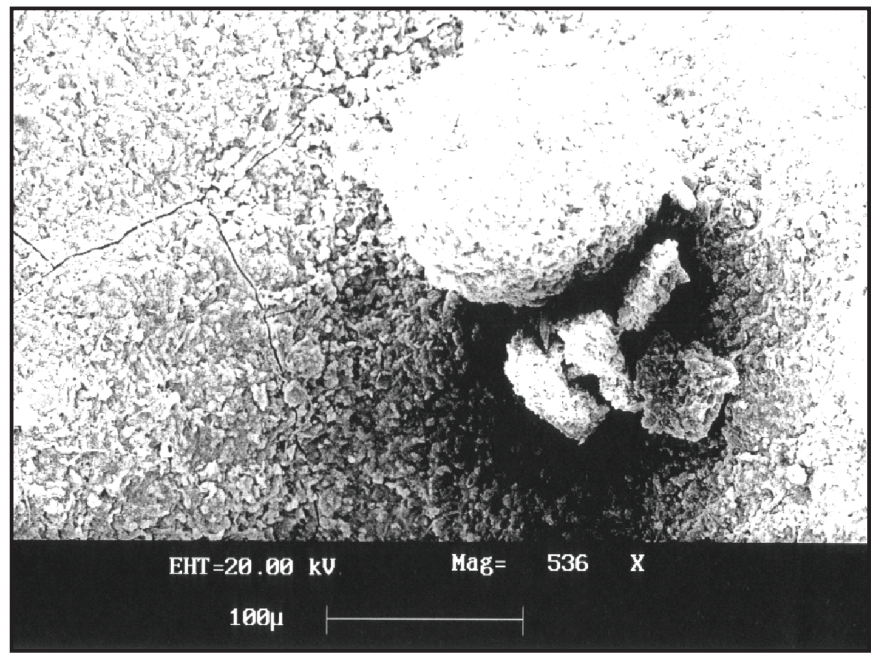

Fig. 2. SEM micrograph of the surface of a silica stalactite (BUND1) composed of an large number of small, irregularly packed, $0.5 \mu \mathrm{m}$ to $15 \mu \mathrm{m}$-sized grains of amorphous opal-A. No $1 \mu \mathrm{m}$ or smaller, pseudo-cubic alunite crystals were found within this opaline material. Note the desiccation cracks that have formed as the opal-A has dehydrated, and the large spherical masses presumably formed when opal-A precipitated around material, possibly quartz sand grains, adhering to the stalactite surface.

In low-temperature settings, alunite usually occurs as microscopic $1 \mu \mathrm{m}$ or smaller, white, pseudocubic crystals (Kerr, 1977; Stoffregen \& Alpers, 1992; Stoffregen et al., 1994; Hill \& Forti, 1997; Polyak \& Provencio, 2001). They are thus of similar or smaller size than the opal-A grains, and despite extensive searching no discrete alunite crystals were visually identified either in thin-section or under the SEM.

In a further attempt to identify alunite crystals within this stalactite material, SEM-EDS X-ray spectra and element mapping were utilised to find areas containing sulphur and potassium. Element maps and X-ray spectra (Fig. 3) of the same powdered material used for the XRD analysis confirm that the elemental composition of the stalactites is dominated by silicon, aluminium and oxygen, but also significant amounts of sulphur (around 2\%-4\%) and potassium (around 1\%-3\%) are found (Fig. 3). Areas of sulphur concentration were identified and visually searched in detail for alunite crystals, but without success, even under high magnification.

These results suggest that the alunite is not to be found as discrete concentrations of crystals, but seems to be concentrated into areas also high in silicon, oxygen, potassium and aluminium (Fig. 3), namely the kaolinite clay.

\section{Stalactite chemical analysis}

Various other chemical analysis were also performed; electron microprobe analysis of a polished sample of BUND1 (Tab. 1), XRF analysis of BUND3, and ICP-OES and CNS analysis for sulphur of five of the powdered XRD samples (BUND5-10) (Tab. 2). These results all confirm that the major element of the stalactites is silica, but they also contain quantities of aluminium, potassium and sodium, small amounts of magnesium, iron, phosphorus, and sulphur, and traces of several minor elements. 
Table 1. Electron microprobe chemical analysis of two transects across BUND1 stalactite perpendicular to long axis. Total excludes $\mathrm{H}_{2} \mathrm{O}$.

\begin{tabular}{lccccccccc}
\hline Sample & $\begin{array}{c}\mathrm{SiO}_{2} \\
(\%)^{2}\end{array}$ & $\begin{array}{c}\mathrm{Al}_{2} \mathrm{O}_{3} \\
(\%)\end{array}$ & $\begin{array}{c}\mathrm{K}_{2} \mathrm{O} \\
(\%)\end{array}$ & $\begin{array}{c}\mathrm{Na}_{2} \mathrm{O} \\
(\%)\end{array}$ & $\begin{array}{c}\mathrm{FeO} \\
(\%)\end{array}$ & $\begin{array}{c}\mathrm{MgO} \\
(\%)\end{array}$ & $\begin{array}{c}\mathrm{CaO} \\
(\%)\end{array}$ & $\begin{array}{c}\mathrm{TiO}_{2} \\
(\%)\end{array}$ & $\begin{array}{c}\mathrm{Total} \\
(\%)\end{array}$ \\
\hline MP1/1 & 86.5 & 1.31 & 0.06 & 0.36 & 0.11 & 0.06 & 0.03 & 0.00 & 88.43 \\
MP1/2 & 78.2 & 1.93 & 0.08 & 0.19 & 0.23 & 0.04 & 0.04 & 0.06 & 80.85 \\
MP1/3 & 67.3 & 1.24 & 0.06 & 0.08 & 0.16 & 0.01 & 0.02 & 0.02 & 68.89 \\
MP1/4 & 90.2 & 2.32 & 0.11 & 0.35 & 0.00 & 0.09 & 0.01 & 0.02 & 93.10 \\
MP2/1 & 84.7 & 1.75 & 0.04 & 0.13 & 0.13 & 0.06 & 0.09 & 0.00 & 86.90 \\
MP2/2 & 89.5 & 1.61 & 0.09 & 0.47 & 0.14 & 0.05 & 0.03 & 0.00 & 91.89 \\
MP2/3 & 86.0 & 1.11 & 0.06 & 0.31 & 0.06 & 0.09 & 0.15 & 0.03 & 87.84 \\
MP2/4 & 88.7 & 1.28 & 0.08 & 0.24 & 0.10 & 0.06 & 0.07 & 0.02 & 90.55 \\
MP2/5 & 81.0 & 4.91 & 0.38 & 0.05 & 0.74 & 0.16 & 0.10 & 0.02 & 87.36 \\
MP2/6 & 101.0 & 0.13 & 0.00 & 0.00 & 0.27 & 0.12 & 0.02 & 0.06 & 101.61 \\
\hline
\end{tabular}

Table 2. Elemental chemical analysis of silica stalactites. BUND3 by XRF, BUND5 to 10 by ICP-OES, with Total Sulphur by CNS analyzer.

\begin{tabular}{lcccccccccc}
\hline Sample & $\begin{array}{c}\mathrm{Al} \\
(\%)\end{array}$ & $\begin{array}{c}\mathrm{S} \\
(\%)\end{array}$ & $\begin{array}{c}\mathrm{K} \\
(\%)\end{array}$ & $\begin{array}{c}\mathrm{Fe} \\
(\mathrm{ppm})\end{array}$ & $\begin{array}{c}\mathrm{Na} \\
(\mathrm{ppm})\end{array}$ & $\begin{array}{c}\mathrm{Ti} \\
(\mathrm{ppm})\end{array}$ & $\begin{array}{c}\mathrm{Ca} \\
(\mathrm{ppm})\end{array}$ & $\begin{array}{c}\mathrm{Mg} \\
(\mathrm{ppm})\end{array}$ & $\begin{array}{c}\mathrm{P} \\
(\mathrm{ppm})\end{array}$ & $\begin{array}{c}\mathrm{Sr} \\
(\mathrm{ppm})\end{array}$ \\
\hline BUND3 & 4.85 & $\mathrm{~nm}$ & 1.45 & 4195 & $\mathrm{~nm}$ & 420 & 0 & 4884 & 1048 & 144 \\
BUND5 & 6.00 & 2.83 & 1.66 & 2960 & 2710 & 790 & 810 & 1020 & 815 & 252 \\
BUND6 & 4.95 & 1.58 & 1.16 & 2310 & 4060 & 545 & 740 & 1260 & 175 & 136 \\
BUND7 & 5.95 & 2.59 & 1.55 & 1800 & 4060 & 505 & 445 & 1080 & 265 & 148 \\
BUND8 & 3.55 & 0.40 & 0.38 & 1380 & 3010 & 500 & 625 & 1190 & 135 & 94 \\
BUND9 & 4.30 & 1.22 & 0.86 & 1270 & 3070 & 595 & 390 & 1110 & 115 & 97 \\
BUND10 & 6.10 & 3.54 & 1.97 & 4280 & 4440 & 575 & 455 & 1110 & 195 & 169 \\
\hline
\end{tabular}

$\mathrm{nm}=$ not measured.

Table 3. Chemical analysis of spring waters by ion chromatography. Duplicate analyses on each water sample.

\begin{tabular}{|c|c|c|c|c|c|c|c|c|c|}
\hline Sample & $\mathrm{pH}$ & $\begin{array}{l}\text { Eh } \\
\text { (mV) }\end{array}$ & $\begin{array}{l}\text { Temp } \\
\left({ }^{\circ} \mathrm{C}\right)\end{array}$ & $\begin{array}{c}\mathrm{F} \\
(\mathrm{ppm})\end{array}$ & $\begin{array}{c}\mathrm{Cl} \\
(\mathrm{ppm})\end{array}$ & $\begin{array}{c}\mathrm{Br} \\
(\mathrm{ppm})\end{array}$ & $\begin{array}{l}\mathrm{NO}^{2} \\
\left(\mathrm{ppm}^{2}\right)\end{array}$ & $\begin{array}{l}\mathrm{NO}^{3} \\
\left(\mathrm{ppm}^{3}\right)\end{array}$ & $\begin{array}{c}\mathrm{SO}_{4} \\
\left(\mathrm{ppm}^{2}\right)\end{array}$ \\
\hline \multicolumn{10}{|l|}{ Springs } \\
\hline $1 a$ & 6.52 & +156 & 18.1 & 0.233 & 28.474 & 0.061 & 0.069 & 0.796 & 2.092 \\
\hline $1 b$ & & & & 0.220 & 27.274 & 0.057 & 0.053 & 0.840 & 2.040 \\
\hline $2 a$ & 6.42 & +154 & 18.1 & 0.240 & 29.870 & 0.056 & 0.049 & 0.862 & 2.540 \\
\hline $2 b$ & & & & 0.236 & 24.839 & 0.052 & 0.054 & 0.702 & 2.042 \\
\hline $3 a$ & 5.94 & +152 & 17.2 & 0.269 & 25.035 & 0.032 & 0.111 & 0.844 & 2.025 \\
\hline $3 b$ & & & & 0.238 & 29.499 & 0.049 & 0.038 & 0.856 & 2.262 \\
\hline $4 a$ & 5.84 & +146 & 17.1 & 0.251 & 30.306 & 0.048 & 0.047 & 0.967 & 2.350 \\
\hline $4 b$ & & & & 0.143 & 34.540 & 0.060 & nd & 1.108 & 2.636 \\
\hline $5 a$ & 4.65 & +153 & 17.1 & 0.263 & 30.528 & nd & 0.091 & 0.748 & 2.384 \\
\hline $5 b$ & & & & 0.293 & 30.078 & 0.057 & 0.042 & 0.811 & 2.389 \\
\hline $6 a$ & 6.07 & +125 & 16.9 & 0.245 & 30.513 & 0.053 & 0.047 & 0.967 & 2.447 \\
\hline $6 \mathrm{~b}$ & & & & 0.248 & 29.909 & 0.045 & nd & 0.835 & 2.488 \\
\hline $7 a$ & 6.27 & +110 & 16.9 & 0.260 & 28.684 & 0.051 & 0.039 & 0.838 & 2.383 \\
\hline $7 b$ & & & & 0.270 & 29.449 & nd & 0.090 & 0.921 & 2.330 \\
\hline $8 a$ & 6.19 & +113 & 16.9 & 0.237 & 32.033 & 0.059 & 0.001 & 0.991 & 2.662 \\
\hline $8 b$ & & & & 0.236 & 30.416 & 0.051 & nd & 0.977 & 2.381 \\
\hline \multicolumn{10}{|l|}{$\begin{array}{l}\text { Surface } \\
\text { Stream }\end{array}$} \\
\hline $9 a$ & 5.08 & +133 & 17.5 & 0.251 & 30.921 & 0.047 & nd & 1.004 & 2.449 \\
\hline $9 b$ & & & & 0.242 & 30.349 & 0.045 & 0.052 & 0.779 & 2.400 \\
\hline
\end{tabular}

\section{Water chemistry}

Although evaporation of tiny droplets of seepage water precipitating opal-A is the prime process controlling silica speleothem growth (Wray, 1997a,b, 1999), the tiny size of these drops prohibits direct measurement of their chemistry. However movement of water through the Hawkesbury Sandstone is common, and within a few hundred metres of the stalactite cave several perennial springs of significant flow volume resurge at the closely-underlying disconformable boundary between the sandstone and the lower estuarine/marine units.

Water from eight of these springs and a nearby surface creek flowing on the sandstone were analysed by ion chromatography (Tab. 3). They were all slightly to moderately acid ( $\mathrm{pH} 4.65$ to 6.52), and welloxidised with Eh between $+110 \mathrm{mV}$ and $+156 \mathrm{mV}$. Dissolved $\mathrm{SO}_{4}{ }^{2+}$ concentrations ranged between 2.03 ppm and 2.66 ppm (Av. 2.35 ppm, Sd. 0.19), similar to those of other natural surface and groundwaters in the surrounding region (Johnson \& Johnson, 1972; Johnson, 1984).

As these sulphate concentrations are not high, alunite is presumably not precipitating directly from these groundwaters; large alunite deposits in hot springs and hyper-saline sedimentary environments usually display sulphate concentrations 2 to 3 orders of magnitude higher (Raymahashay, 1968; Alpers et al., 1992; Long et al., 1992). If, however, other factors such as evaporative concentration of groundwater forming the stalactites, or oxidation of reduced ironbearing waters, are considered, these concentrations may be sufficient for the formation of alunite under favourable conditions.

\section{DISCUSSION}

Various XRD spectra and SEM-EDS spectra and element maps all suggest the presence of small quantities of alunite and the possibility of natroalunite within these stalactites. Although the formation of these sulphate minerals within silica stalactites is seemingly unusual, their presence is not inconsistent with general opal-alunite relationships elsewhere; for example, Barnes \& Townsend (1982), Bird et al., (1990), Dill (2001), Thiry et al. (2006) and Blanco et al., (2008) all report the co-formation of alunite and non-speleothem groundwater opal in soil and weathering profiles.

Authigenic speleogenetic alunite-group minerals in cave sediments, and their more widespread presence in weathering profiles, are usually taken as clear indicators of the reaction of sulphate-acidified groundwater on kaolinite, illite, smectite clays or mica (Keller et al., 1967; Goldbery, 1980; Chitale \& Güven, 1987; Rouchy \& Pierre 1987; Polyak \& Güven, 1996; Hill \& Forti, 1997; Polyak et al., 1998; Polyak \& Provencio, 2001; Blanco et al., 2008), or reactions of acidic solutions with shale matrix, dolomite, or by evaporation (Martini, 1980). Therefore the presence of alunite within these stalactites, but not within the overlying sandstone or any other Sydney-region speleothem so far studied, strongly suggests that it is an authigenic speleothemic product formed by highly localised, but conceivable, geochemical factors. 

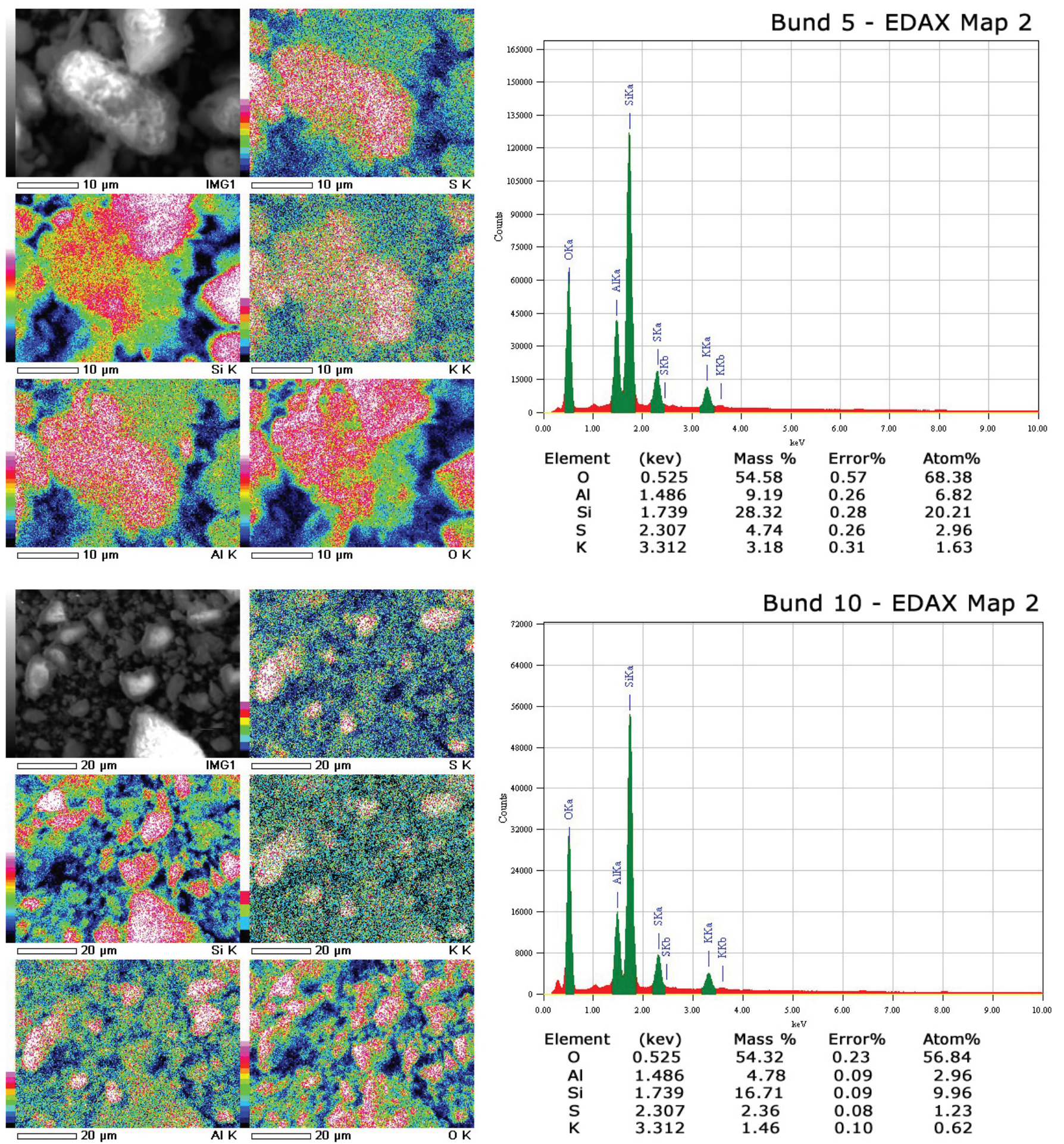

Fig. 3. SEM energy dispersive X-ray spectra and element maps of powdered samples BUND5 and BUND10, the same sample material used for XRD analysis. Element maps for S, Si, K, Al and O. Table indicates relative percentages of selected elements. Sulphur (alunite) is concentrated into certain areas, those also typically high in $\mathrm{Si}, \mathrm{K}, \mathrm{Al}$ and $\mathrm{O}$, presumably the kaolinite clay. However, even at higher magnification, individual pseudo-cubic alunite crystals were not visible.

Goldbery (1978, 1980) identified three critical stages or conditions for the generation of diagenetic non-hydrothermal alunite. Firstly, generation of $\mathrm{H}_{2} \mathrm{~S}$ and/or pyrite under anaerobic conditions (stage 1 ), followed by a change to oxidising conditions and the formation of sulphuric acid $\left(\mathrm{H}_{2} \mathrm{SO}_{4}\right)$ (stage 2), and finally (stage 3 ) the alteration of clay minerals (presumably kaolinite and/or illite in this instance) by the sulphuric acid generated in stage 2 .
Each of Goldbery's stages is plausible here. Sulphur-bearing minerals are rare within the Hawkesbury Sandstone, but pyrite is quite common within the closely underlying estuarine/marine sediments (Standard, 1969; Herbert \& Helby, 1980) and spring waters contain modest levels of dissolved sulphate. Well-oxidised conditions are evidenced by the relatively high $\mathrm{Eh}$ of the springwaters, very tiny evaporating water droplets on the stalactites, and 


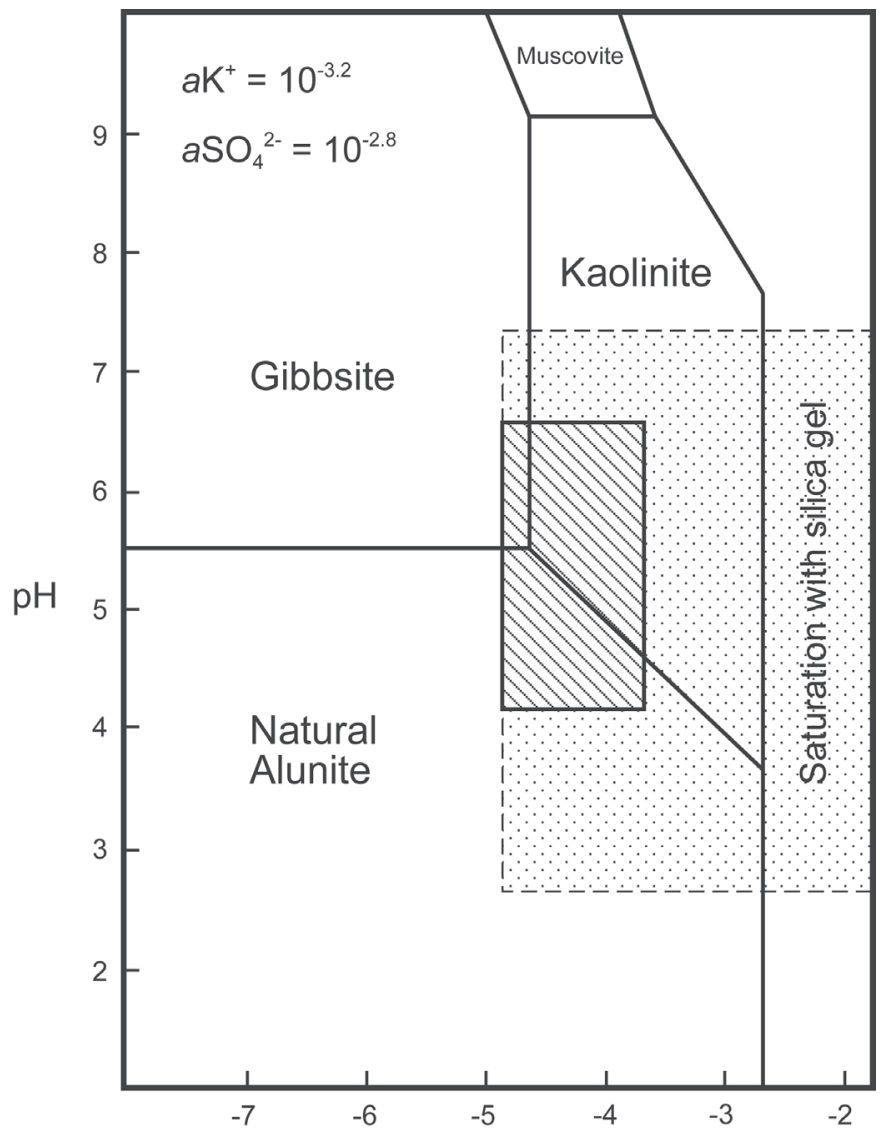

$\log \mathrm{aH}_{4} \mathrm{SiO}_{4}$

Fig. 4. Stability fields of amorphous silica, gibbsite, kaolinite, muscovite, and natural alunite at $25^{\circ} \mathrm{C}$ in acid environments (after Raymahashay, 1968, Table 10). Shaded area shows the expected range of geochemical conditions within these stalactites. Hatched zone shows range of $\mathrm{pH}$ and dissolved silica reported in local surface and groundwater

by the common presence of oxidised iron minerals throughout the stalactites. The generation of acid conditions may particularly be encouraged if $\mathrm{Ca}^{2+}$ and $\mathrm{Mg}^{2+}$ levels are low, as they are here. Clay minerals such as kaolinite and illite necessary for the acidalteration pathway are plentiful throughout the sandstone, and common within the stalactites.

Thus an acidic-reaction pathway before silica saturation is reached and opal-A precipitates is compatible with the alteration of kaolinite to alunite by sulphate-rich groundwater suggested by Raymahashay (1968). The activities of $\mathrm{K}^{+}, \mathrm{SO}_{4}^{2-}, \mathrm{H}_{4} \mathrm{SiO}_{4}$ and $\mathrm{pH}$ are the controlling factors (Raymahashay, 1968; Chitale \& Güven, 1987), and the equilibrium may shift to the right or left, with kaolinite being converted to alunite releasing additional silica for opal formation, or alunite replaced by kaolinite removing silica from solution.

At $25^{\circ} \mathrm{C}$, the thermodynamic stability fields of kaolinite and alunite (Raymahashay, 1968) show that alunite will not form in near-neutral $\mathrm{pH}$ solutions (Fig. 4). However at low silica concentrations below a $\mathrm{pH}$ of about 5.5, alunite is more stable than kaolinite, but will convert to kaolinite as the $\mathrm{H}_{4} \mathrm{SiO}_{4}$ concentration increases toward saturation and opal-A precipitation (i.e. during evaporation of the tiny water droplets seen on stalactites). The $\mathrm{H}_{4} \mathrm{SiO}_{4}$ activity of the stability boundary between alunite and kaolinite increases with decreasing $\mathrm{pH}$ (Fig. 4) (Raymahashay, 1968), therefore, if the $\mathrm{pH}$ drops below about 3.7, alunite or natroalunite might conceivably form within these stalactites and persist right up to the point of silica saturation and opal-A precipitation, and some might remain preserved within the opal-A mass rather than reverting to kaolinite. The range of measured springwater $\mathrm{pH}$ and typical dissolved silica concentrations in the region fall within the thermodynamic stability fields of this opal-A-kaolinitealunite system.

An alternative to sulphate-derived acid conditions may come from the oxidation and hydrolysis (ferrolysis) of hydrous $\mathrm{Fe}^{2+}$-oxides. Mann (1983), Thiry et al. (2006) and Blanco et al. (2008) have all suggested that in weathering profiles ferrolysis of dissolved $\mathrm{Fe}^{2+}$ compounds can provide $\mathrm{pH}$ sufficiently low for the conversion of kaolinite to alunite coincident with the precipitation of opal-A. Such a process where anoxic iron-rich groundwater mixes with oxygenated waters may account for the opaque iron materials within the stalactites (Tab. 1 and 2), and could conceivably lead to the acidic conditions needed for alunite formation.

Another possibility is some form of micro-chemical action by bacteria or other micro-organisms in the precipitation of alunite. Microbial communities are abundant in many active $\mathrm{H}_{2} \mathrm{SO}_{4}$ caves today, and their excretions are believed to have played an important role in the alteration of clays and other insoluble minerals during speleogenesis (Engel et al., 2000; Hose et al., 2000; Polyak \& Provencio, 2001). It was not possible to examine either of these possible alternatives in detail here, but they represent avenues for potentially fruitful future study.

The exact mechanism for the formation of the small quantities of natroalunite that are suggested is uncertain. Chitale \& Güven (1987) note that natroalunite may form if $\mathrm{Na}^{+}$substitutes for $\mathrm{K}^{+}$, and it is possible that it could form by cation exchange on pre-existing alunite, or by direct precipitation from solutions of appropriate composition.

Several other uncertainties exist and offer avenues for further exploration. The dominance of the opal-A and kaolinite over the alunite has not allowed the determination of the exact composition of the alunite or natroalunite within these stalactites, and has not permitted the calculation of the alunite unit-cell dimensions. Some slight differences are also seen between the properties of the XRD spectra of this alunite compared with the published characteristics of pure hydrothermal alunite. However, such variations are not uncommon (Keller et al., 1967), and they are not believed to cast doubt on the mineral identification. For example, the typically strong $2.29 \AA$ and $1.92 \AA$ peaks of pure alunite are attenuated on the stalactite XRD spectra, and seem to be shifted slightly. This has presumably resulted from the micro-crystalline alunite being mixed with large amounts of kaolinite and opal-A, slight variations in the chemistry of the different samples, or poor crystal ordering (perfection) delimiting crystal size as suggested by Keller et al. (1967). 


\section{CONCLUSIONS}

A number of XRD and SEM-EDS spectra and element maps have provided evidence for the occurrence of authigenic alunite in small opal-A stalactites, produced during the normal silica stalactite-forming process. These spectra are the first known evidence for low temperature origin of alunite in silica speleothems, and only the second known instance of stalactitic alunite.

This low temperature co-production of alunite with speleothem opal-A seems to be an unusual geochemical process, but is consistent with observations of the authigenic formation of alunite and groundwater opal elsewhere. The presence of both alunite and kaolinite suggests that the geochemical conditions within these stalactites lie close to the opal-kaolinitealunite stability boundary at moderately acidic $\mathrm{pH}$. Reaction of sulphuric acid, generated from pyrite, with kaolinite is the probable mechanism of alunite genesis. Iron oxidation and ferrolysis, or unknown biologic-mediated mechanisms, might also lower $\mathrm{pH}$ sufficiently to contribute to alunite production.

It is also suspected that small amounts of natroalunite are present, but the XRD diffraction patterns are not sufficiently clear for positive identification.

To date, alunite-group minerals have not been discovered in any other Sydney region stalactites, but none have been analysed that have formed as close to pyrite-bearing estuarine/marine rocks as these. Further detailed field and laboratory investigations of other silica speleothems from this and other areas area are therefore warranted.

\section{ACKNOWLEDGMENTS}

The author would like to acknowledge the kind assistance and input of Dr Bryan Chenhall, Jayne Thomas, and the School of Earth and Environmental Sciences, University of Wollongong. Several colleagues and anonymous reviewers provided constructive suggestions for improving earlier versions of this manuscript.

\section{REFERENCES}

Alpers C.N., Rye R.O., Nordstrom D.K., White L.D. \& King B.S., 1992 - Chemical, crystallographic and stable isotopic properties of alunite and jarosite from acid-hypersaline Australian lakes. Chemical Geology, 96: 203-226.

Barnes L.C. \& Townsend I.J., 1982 - Opal: South Australia's gemstone. South Australian Geological Survey Handbook, 5, Adelaide, 157 p.

Bayliss P., Loughnan F.C. \& Standard J.C., 1965 Dickite in the Hawkesbury Sandstone of the Sydney Basin, Australia. The American Mineralogist, 50: 418-426.

Bird M.I., Andrew A.S., Chivas A.R. \& Lock D.E., 1989 - An isotopic study of surficial alunite in Australia 1. Hydrogen and Sulphur isotopes. Geochimica et Cosmochimica Acta, 53: 3223-3237.

Bird M.I., Chivas A.R. \& McDougall I., 1990 - An isotopic study of surficial alunite in Australia 2. Potassium-argon geochronology. Chemical Geology (Isotope Geoscience Section), 80: 133-145.
Blanco J.A., Armenteros I. \& Huerta P., 2008 - Silcrete and alunite genesis in alluvial palaeosols (late Cretaceous to early Palaeocene, Duero Basin, Spain). Sedimentary Geology, 211: 1-11.

Briceño H.O. \& Schubert C., 1990 - Geomorphology of the Gran Sabana, Guyana Shield, southeastern Venezuela. Geomorphology, 3: 125-141.

Brindley G.W. \& Brown G. (Eds.), 1980 - Crystal Structures of Clay Minerals and their X-ray Identification. Mineralogical Society Monograph No. 5, Mineralogical Society, London, 495 p.

Carreño R. \& Urbani F., 2004 - Observaciones Sobre las Espeleotemas del Sistema Roraima Sur (in Spanish, English abstract). Boletín de la Sociedad Venezolana de Espeleología. 38: 28-33.

Chitale D.V. \& Güven N., 1987 - Natroalunite in a laterite profile over Deccan Trap Basalts at Matanumad, Kutch, India. Clays and Clay Minerals, 35: 196-202.

Deyella C.L., Ryeb R.O., Landisb G.P. \& Bissigc T., 2005 - Alunite and the role of magmatic fluids in the Tambo high-sulfidation deposit, El Indio-Pascua belt, Chile. Chemical Geology, 215: 185-218.

Dill H.G., 2001 - The geology of aluminium phosphates and sulphates of the alunite group minerals: a review. Earth-Science Reviews, 53: 35-93.

Ece O.I. \& Schroeder P.A., 2007 - Clay mineralogy and chemistry of halloysite and alunite deposits in the Turplu area, Balikesir, Turkey. Clays and Clay Minerals. 55: 18-35.

Ece O.I., Schroeder P.A., Smilley M.J. \& Wampler J.M., 2008 - Acid-sulphate hydrothermal alteration of andesitic tuffs and genesis of halloysite and alunite deposits in the Biga Peninsula, Turkey. Clay Minerals, 43: 281-315.

Engel A.S., Bennett P.C. \& Stern L.A., 2000 - Mineralogic and geochemical consequences of microbial habitat modification in sulfidic karst systems: Examples from the Kane Caves, Wyoming. Eos, Transactions, American Geophysical Union, 81: F215.

Finlayson B.L. \& Webb J.A., 1985 - Amorphous Speleothems. Cave Science, 12: 3-8.

Goldbery R., 1978 - Early diagenetic, nonhydrothermal Na-alunite in Jurassic flint clays, Makhtesh Ramon, Israel. Bulletin of the Geological Society of America, 89: 687-698.

Goldbery R., 1980 - Early diagenetic, Na-alunite in Miocene algal mat intertidal facies, Ras Sudar, Sinai. Sedimentology, 27: 189-198.

Herbert C. \& Helby R. (Eds.), 1980 - A Guide to the Sydney Basin, Geological Survey of New South Wales, Sydney, 603 p.

Hill C.A. \& Forti P., 1997, Cave Minerals of the World, 2nd ed, National Speleological Society, Huntsville, Alabama, $464 \mathrm{p}$.

Hose L.D., Northup D.E., Boston P.J., DuChene H.R., Palmer A.N. \& Palmer M.V., 2000 - Microbiology and geochemistry in a hydrogen-sulphide-rich karst environment. Chemical Geology, 169: 399423.

Jone J.B. \& Segnit E.R., 1971 - The nature of Opal: 1. Nomenclature and Constituent Phases. Journal of the Geological Society of Australia, 18: 57-68. 
Johnson M., 1984 - Analysis of surface waters from the Dapto-Kiama-Robertson Region of the Sydney Basin. Mineral Resources Development Laboratory, Department of Mineral Resources, Sydney, N.S.W.

Johnson M. \& Johnson W.D., 1972 - Occurrence of silica in the natural waters of the HuntleyRobertson District, southern New South Wales. Australian Journal of Marine and Freshwater Research, 23: 105-19.

Keller W.D., Gentile R.J. \& Reesman A.L., 1967 Allophane and Na-rich alunite from kaolinitic nodules in shale. Journal of Sedimentary Petrology, 37: 215-220.

Kerr P.F., 1977 - Optical Mineralogy, 4th ed., McGrawHill, New York, 492 p.

Khalaf F.L., 1990 - Diagenetic alunite in clastic sequences, Kuwait, Arabian Gulf. Sedimentology, 37: 155-164.

Long D.T., Fegan N.E., McKee J.D., Lyons W.B., Hines M.E. \& Macumber P.G., 1992 - Formation of alunite, jarosite and hydrous iron oxides in a hypersaline system: Lake Tyrell, Victoria, Australia. Chemical Geology, 96: 183-202.

Mann A.W., 1983 - Hydrogeochemistry and weathering on the Yilgarn Block, W.A. - Ferrolysis and heavy metals in continental brines. Geochimica et Cosmochimica Acta, 47: 181-190.

MartiniJ.E.J, 1980-Mbobomkulite, Hydrombobomkulite and Nickelalumite, new minerals from Mbobo Mkulu Cave, Eastern Transvaal. Annals Geological Survey South Africa, 14: 1-10.

Martini J.E.J, Wipplinger P.E. \& Moen H.F.G., 1997 - Mbobo Mkulu Cave, South Africa. In: Hill C.A. \& Forti P.(Eds.) - Cave Minerals of the World, National Speleological Society, Huntsville, 336339.

Mutlua H., Sariiza T.K. \& Kadira S., 2005 Geochemistry and origin of the Xaphane alunite deposit, Western Anatolia, Turkey. Ore Geology Reviews, 26: 39-5.

Pells P.J.N., 1977 - Measurement of engineering properties of Hawkesbury Sandstone. Australian Geomechanics Journal, G7: 10-20.

Polyak V.J. \& Güven N., 1996 - Alunite, natroalunite and hydrated halloysite in Carlsbad Cavern and Lechuguilla Cave, New Mexico. Clays and Clay Minerals, 44: 843-850.

Polyak V.J., McIntosh W.C., Güven N. \& Provencio P., 1998 - Age and origin of Carlsbad Cavern and related caves from 40Ar/39Ar of alunite. Science, 279: 1919-1922.

Polyak V.J. \& Provencio P.P., 2000 - Summary of the timing of sulfuric-acid speleogenesis for Guadalupe caves based on ages of Alunite. Journal of Cave and Karst Studies, 62: 72-74.
Polyak V.J. \& Provencio P., 2001 - By-product materials related to $\mathrm{H}_{2} \mathrm{~S}-\mathrm{H}_{2} \mathrm{SO}_{4}$-influenced speleogenesis of Carlsbad, Lechuguilla, and other caves of the Guadalupe Mountains, New Mexico. Journal of Cave and Karst Studies, 63: 23-32.

Raymahashay B.C., 1968 - A geochemical study of rock alteration by hot springs in the Paint Pot Hill area, Yellowstone Park. Geochimica et Cosmochimica Acta, 32: 499-522.

Rouchy J. \& Pierre C., 1987 - Authigenic natroalunite in middle Miocene evaporites from the Gulf of Suez (Gemsa, Egypt). Sedimentology, 34: 807-812.

Standard J.C., 1969 - Hawkesbury Sandstone. Journal of the Geological Society of New South Wales, 16: 407-417.

Stoffregen R.E. \& Alpers C.N., 1992 - Observations on the unit-cell dimensions, $\mathrm{H}_{2} \mathrm{O}$ contents and delta $D$ values of natural and synthetic alunite. American Mineralogist, 77: 1092-1098.

Stoffregen R.E., Rye R.O. \& Wasserman M.D., 1994 Experimental studies of alunite: $1 .{ }^{18} \mathrm{O}-{ }^{16} \mathrm{O}$ and $\mathrm{D}-\mathrm{H}$ fractionation factors between alunite and water at 250-450 ${ }^{\circ} \mathrm{C}$. Geochimica et Cosmochimica Acta, 58: $903-916$.

Thiry M., Milnes A.R., Rayot V. \& Simon-Coinçon R., 2006 - Interpretation of palaeoweathering features and successive silicifications in the Tertiary regolith of inland Australia. Journal of the Geological Society, 163: 723-736.

Urbani, F., 1976 - Opalo, Calcedonia y Calcita en la Cueva del Cerro Autano (Am 11), Territorio Federal Amazonas, Venezuela (in Spanish, English summary). Boletín de la Sociedad Venezolana de Espeleología, 7: 129-145.

Wiegand J., Fey M., Haus N. \& Karmann I., 2004 Geochemische und hydrochemische Untersuchung zur Genese von Sandstein- und Quarzitkarst in der Chapada Diamantina und in Eisernen Viereck (Brasilien). Zeitschrift der Deutschen Geologischen Gesellschaft, 155: 61-90.

Wray Robert A.L., 1997a - A global review of solutional weathering forms on quartz sandstones. Earth Science Reviews, 42: 137-160.

Wray Robert A.L., 1997b - The formation and significance of coralline silica speleothems in the Sydney Basin, Southeastern Australia. Physical Geography, 18: 1-16.

Wray Robert A.L., 1999 - Opal and chalcedony speleothems on quartz sandstones in the Sydney region, southeastern Australia. Australian Journal of Earth Sciences, 46: 623-632.

Young R.W., Wray Robert A.L. \& Young A.R.M., 2009 - Sandstone Landforms, Cambridge University Press, Cambridge, 320 p. 